\title{
MEDICAL TESTIMONY IN PERSONAL INJURY CASES
}

\author{
Frederic E. Elliotr* and Ramsay Sillman†
}

The journal in which these lines appear carried an advertisement in the issue for June, I935, of a "Preparation Manual for Accident Cases," for which it was claimed "This is NOT a text book, but a practical manual intended for the practicing attorney-outlining in clear, understandable detail, precisely what steps to take to build up an accident case to its point of MAXIMUM effectiveness." (Capitals by the advertiser.)

Thus, one does not have to go far for evidence that under the legal procedure current today, accident cases are not settled by a dispassionate inquiry into the facts, but instead they are "built up" to their "point of maximum effectiveness."

The news items emanating from the meeting of the American Bar Association in Los Angeles this year lead one to believe that the Bar Association is becoming acutely conscious that public opinion is not entirely friendly toward the legal profession. It might be pointed out that criticism of some of the accepted legal procedure is not anything particularly new. When a graduating class of Harvard Medical School is addressed on its way out into the world, it is usual to select a speaker whose opinions are reasonably representative of the most highly respectable circles of medicine. Dr. J. W. Courtney said to the Harvard graduating class of $1915:^{1}$

"The present mode of procedure in our courts, in so far as medical testimony is concerned, is not a particularly edifying one. To illustrate this point, let us take, for example, a case of the type which is most commonly met with in everyday work of the courtsan action of tort for personal injuries. In such a case, the plaintiff is practically always of the proletariat class; the defendant, a public service corporation, or an insurance company. The army of witnesses on either side is generally appalling. Of these the medical ones alone concern us. They are of two hostile camps, and prepared to attempt, under solemn oath, to uphold opinions diametrically opposed, yet supposedly derived from a single series of facts and observations.

- M.D., 1904. Engaged in the practice of medicine in New York City, specializing since $19 \times 8$ in roentgenology, with frequent appearance in court since that date as an expert witness in roentgenology. Chairman, Committee on Economics of the New York State Medical Society.

+ A.B., 1914, M.D., 1917, Cornell University. Engaged in the practice of medicine in New York City since 1923, specializing in roentgenology. Roentgenologist to the Beckman Strect Hospital, 1920-1931; assistant roentgenologist to the Manhattan Eye, Ear, and Throat Hospital since 193X. President of the New York Roentgen Society. Contributor to scientific periodicals.

${ }^{1}$ This address was published in The Boston Medical and Surgical Journal, Jan. 6, 1916. 
"The situation is a deplorable one, and nobody discerns the glaring wrong of it all with clearer vision than certain high-minded men from our ranks, who have long striven to procure legislative enactment looking toward the abolition of this evil.

"To me, for many reasons, which I cannot here enumerate, it seems hopeless to expect that legislative appeal on the part of such men will ever be fruitful of the desired results. Hence, it is the bounden duty of every man in the profession so to shape his conduct toward cases which promise to eventuate into court proceedings, that due respect will be given his opinion, that he will not merit the biting sarcasm, the sneers, the raillery and general brow-beating of opposing counsel. And most of all, that through his efforts the ends of justice will really be, accomplished."

Dr. Courtney died June 6 , I928 at the age of sixty. It is lamentable that he did not live to see the day when a law journal invited physicians to submit suggestions for a symposium which is heralded by that journal's own statement that "The rules governing the rôle of the expert witness in criminal and civil litigation have long been a source of dissatisfaction to bench, bar, and the scientific professions alike." If these rules are to be continued indefinitely, the writers have no suggestions to make. If the legal profession has come to the point where it really desires to scrap the present procedure and go about the adoption of a proper one, it is our firm belief that the medical profession will spare no effort to coöperate in such a project.

\section{II}

Under the hypothetical improved procedure which the writers have in mind, the "building up" of an accident case will be conspicuous by its absence. Cases will not be "built up." They will be settled on a dispassionate examination of the facts, and medical expert witnesses will be the servants of the court alone, not the hirelings of the plaintiff or the defendant. The medical expert witness will be allowed to tell all he knows, regardless of whether it favors or detracts from one side or the other. The final opinions as to liability, nature of injury, and indemnity deserved, will not be left to a lay jury of twelve. 'Cases will be heard not before a lay jury which may or may not be swayed by the lawyer's bag of emotional tricks, but by a tribunal of two or in some cases three judges. One judge will be a legal judge, to pass on the law and on the liability. The second judge will be a physician, known as a medical judge; not, however, the same thing as the medical referee in New York State Workmen's Compensation procedures, a position often occupied by a non-medical man. The function of the medical judge will not be to judge on law, but on questions as to the causal relationship between the defendant's act and the injury for which plaintiff seeks damages and as to the extent and permanency of the injuries thus caused. The third judge, in cases requiring one, will represent the lay point of view, if the case is one with a particular industrial bearing.

It has been of no little interest to the junior author to learn that a plan, essentially similar to his own, was formulated earlier and independently by no less an authority on the law than Chief Judge Frederick E. Crane of the New York Court of Appeals, 
in an address before the Association of the Bar of the City of New York on January $28,{ }^{2} 93^{2}{ }^{2}$ Discussing the delay in obtaining trial, particularly in cases arising out of automobile accidents, he said:

"We find our court calendars frightfully congested. In this county the trial of cases is at least two years behind, and in Kings County, Brooklyn, the calendars are four years behind, in Queens and Nassau counties, three. In the City Court of Brooklyn, which is about six years old, I am informed that it is over five years behind. The lawyers tell me that their clients are obliged to settle their cases at nominal figures because they are unable to wait for litigation. Financial reasons demand a sacrifice of their rights. As likely as not after a verdict a case is carried up on appeal and reversed either by the Appellate Division and the Court of Appeals, and the same procedure starts all over again. ... The number of automobile accident cases has added materially to the number of the cases upon our calendar. . . . What a speedy disposition there would then be of all these automobile accident cases when the court could appoint arbiters without limit-a lawyer, a doctor, a layman - who would dispose of the case as satisfactorily, yes, more satisfactorily than most of the courts and juries."

The writers, having been asked to contribute their ideas, have felt free to outline their conception of what the ideal arrangement would be, though there is no implication that they expect to see it in operation any time soon. In this connection, it should not be amiss to mention that the address by Judge Crane, to which reference has just been made, was endorsed by the Committee on Economics of the Medical Society of the State of New York, and the Committee recommended that the House of Delegates approve of the principle of compulsory arbitration of automobile accident case claims, and that the secretary of the Society transmit the expressions of their approval to Judge Crane. Mr. L. J. Brosnan, who, as counsel for the New York State Medical Society, defends the members in malpractice cases, questioned this recommendation in the following words:

"Section I49, paragraph A of this report approves the principle of compulsory arbitration in automobile accident cases. This approval is based upon a recommendation by Judge Crane of the Court of Appeals that it would be a desirable thing for the congested calendars to have automobile accident cases decided by a board of arbitration. I desire to point out, however, that if the lawyers who are now handling automobile accident cases on behalf of plaintiffs, are deprived of this business by legislation, they will necessarily invade the field of malpractice on the plaintiff's side. This, I think, should be taken into consideration in determining whether this recommendation of the Medical Economics Committee should be approved."

This is all a matter of public record in the New York State Journal of Medicine for April 15 and June 15, 1932. Truly, if it isn't one thing that stands in the way of legal reforms, it's another.

Obstacles to its adoption aside, we are trying to formulate a procedure which will provide a maximum appeal to reason and a minimum appeal to emotion. We are prepared to be entirely cordial to other ideas as to details, provided that they adhere

\footnotetext{
2 The address was published in The New York Law Journal, Jan. 29, 1932.
} 
to this fundamental principle. We have visualized an individuality which has no strict counterpart in current affairs, namely, the medical judge. This office should be held by a man of sound medical experience and unquestioned integrity. As for the third judge, representing the laity or industry involved, he already is found on arbitration boards which are working today, and it is a matter of record that the idea works out satisfactorily.

The writers are aware that any procedure which dispenses with the jury is likely to present constitutional difficulties, and they do not expect the legal profession to set aside the Constitution. Since a consideration of constitutional problems is without their province, the writers have consulted a member of the New York State Bar for his opinion on this point from which the following statement is quoted.

"In suggesting the removal of all injury cases from courts of general jurisdiction and the creation of specially constituted tribunals for their trial without a jury, your proposal presents constitutional problems of grave difficulty. The federal and state constitutions guarantee the common law right to trial by jury in civil as well as criminal cases. It is true that in civil cases (and, in many states, in most criminal cases) jury trial may be waived, but this requires the consent of the parties. Such studies as have been made of the use of the jury in civil trials indicate that waiver is a common enough phenomenon, but from the standpoint of your inquiry it is significant to note that the jury is seldom waived in negligence cases. Thus, a four-year study in Connecticut showed that although negligence cases tried were only 2.7 times as numerous as contract cases tried, the number of negligence cases tried before juries was 0.5 times as great as the number of contract cases so tried." ${ }^{3}$

"Workmen's compensation laws afford a precedent for the abolition of the common law trial of negligence claims, but they substitute not merely an administrative for a judicial determination of liability but also a plan of compensation for industrial accidents which permits the injured employee to obtain compensation irrespective of the fault of his employer. If a similar scheme of compensation were devised and adopted for automobile injuries, as has often been suggested, then doubtless a tribunal of the sort you propose could constitutionally be utilized for the determination of compensation.

"If no compensation plan accompanied the creation of a special court for personal injury cases, then the privilege of jury trial would have to be retained unless at least the state constitutions were amended. However, the workmen's compensation statutes of some states suggest a compromise solution. They permit employers to stay outside the compensation system and remain subject only to common law liability, but they penalize the employer doing so by depriving him of his most valuable defenses-the fellow-servant rule, assumption of risk, etc. If a tribunal of the sort you have in mind were created as an alternative forum for the trial of personal injury cases and if changes in the law were made to render recourse to jury trial less profitable to plaintiffs, the practical substitution of the former for the latter might be effected. Among the sanctions which might be employed to this end, there might be a drastically shorter statute of limitations and a stringent limitation on the amount of damages similar to that existing in many wrongful death statutes."

"See Clark and Shulman, Jury Trial in Civil Cases-A Study in Judicial Administration (1934) 43 YALE L. J. 867,87 I, n. 7. 


\section{III}

Having given our idea of what would be an ideal procedure, we now offer what it is hoped are feasible suggestions for improvement that do not embody any changes which could not be brought about within a reasonable time.

x. Whenever negligence resulting in personal injury is the basis of a claim for damages, notice that action will be brought on such claim should be required to be given within a limited number of weeks after the injury, and a preliminary hearing should thereupon be held before a judge or referee wherein testimony of witnesses. for the plaintiff as to the facts of the occurrence and the extent of the injury may be taken, subject to cross-examination by defendant's counsel. At the conclusion of this hearing, an order should be made dismissing the complaint if facts sufficient to estab. lish a prima facie cause of action are not proffered. If a prima facie case is made out, the testimony taken at the hearing may be introduced in the trial of the action on cross-examination or on direct examination to refresh recollection or directly if the witness is dead or has removed from the jurisdiction.

This proposal is advanced as a means of obviating the absurdities and the wellschooled perjury which arise when witnesses are called upon to recall specific and minute details of incidents from three to five years after their occurrence. We recall an instance of a case in a Kings County Supreme Court which points the need for prompt action in establishing the basis of the plaintiff's case. An automobile had pinched a small boy's foot. The phalanx of one toe had been fractured-no displacement and no deformity. Actually, a minor injury which, if sustained while at play, would have been cause for only slight complaint by the boy. Because of the alleged negligence of the automobile driver, an action was started for $\$ 25,000.00$ damages, and the boy was transported to and from school and, literally, carried in arms to and from his seat in the school room and his father's car-two trips each day- for six weeks. The trial was delayed by congestion of the calendar and four years had elapsed before the witnesses appeared on the stand.

Just preceding the trial the insurance company offered $\$ 250.00$ in settlement and the father was ready to accept, but the judge, in protection of the interest of the minor, would not permit its acceptance, saying, "If the injury justified an action for $\$ 25,000.00$ the sum offered in settlement is not fair to the infant, and if he was not seriously injured the settlement is unfair to the defendant."

Witnesses appeared in succession, the boy, his mother, the father and the family physician. There was agreement between no two of them as to which toe had been injured, there was some disagreement as to which foot had been involved, and only one witness agreed with the details of the bill of particulars. The family physician by chance was the family physician to the presiding judge, and was thereby spared the biting sarcasm which might have been directed very justly to the state of his case record. (Parenthetically, we know that this same physician produced the stub record of a birth after eighteen years-when the Health Department records had 
been misplaced or lost.) Through the courtesy of the judge, an adjournment gave opportunity for the physician to refresh his memory by consulting the records of the roentgenologist who had made the $\mathrm{x}$-ray examination and, upon returning to court, he "corrected" his testimony. The jury gave its decision to the defendant.

2. Eliminate the present contingent fee system and substitute therefor an award to be fixed by the court for the services of the attorney for the plaintiff according to the conditions in each given case. Possibly impose a penalty upon the attorney who brings an action for negligence for which there are no reasonable grounds.

That the fee system currently in use is a source of scandal and in urgent need of reform is indicated by the following excerpt from the report of Justice Wasservogel at the conclusion of the "ambulance chasing" investigation, over which he presided in New York City in 1928. Justice Wasservogel made the following proposal for change, ${ }^{4}$ a recommendation substantially according with that made by Justice Faber after a similar investigation in Brooklyn ${ }^{5}$ and with that which the writers propose above.

"I have ... come to the conclusion that all contingent retainers in actions for personal injuries should be placed under the supervision of the courts, in order adequately to protect claimants in their relations with attorneys, and to eradicate the abuses which have been practiced upon the courts by attorneys. This added burden on the courts is necessary to remedy the situation disclosed by this investigation. I think that most adult personal injury claimants are in the same position as infant claimants when it comes to dealing with attorneys, and require the same protection from the courts. I therefore recommend that section 474 of the Judiciary Law be amended, so as to embrace within its terms the cases of adults who have claims for personal injuries. This will require attorneys, who secure contingent retainers from all such claimants, to apply for an order fixing their compensation."

3. Develop standards, and secure statutory authorization, for use in the determination of the degree and consequences of personal injuries by reference to the extent of deformity and disfigurement and by the percentage of lost function consequent upon the injury.

That there is a need for a more accurate method of determining the extent of personal injuries was recognized as early as IgIr by the Washington Supreme Court in a decision ${ }^{8}$ upholding that state's workmen's compensation law in which the court said:

"The common-law system of making awards for personal injuries has no such inherent merit as to make a change undesirable. While courts have often said that the question of amount of compensation to be awarded for a personal injury is one peculiarly within the province of the jury to determine, the remark has been induced rather because no better method for solving the problem is afforded by that system, than because of the belief that

\footnotetext{
'See Message of the Governor Transmitting the Final Reports on the Inquiry by the Court into Certain Abuses and Illegal and Improper Practices in Connection with the Administration of Justice, 1929 N. Y. LEgrs. Doc. No. 52, Exhibit A, p. II.

Id., Exhibit B, p. 37 .

- State ex rel, Dayis-Smith Co. v. Clausen, 65 Wash. 156, iry Pac. I10I (I911).
} 
no better method could be devised. No one knows better than judges of courts of nisi prius and of review that the common-law method of making such awards, even in those instances to which it is applicable, proves in practice, most unsatisfactory. All judges have been witnesses to extravagant awards made for most trivial injuries, and trivial awards made for injuries ruinous in the nature; and perhaps no verdicts of juries are interfered with so often by the courts as verdicts making awards in such cases. There is no standard of measurement that the court can submit to the jury by which they can determine the amount of the award. The test of reasonableness means but little to the ordinary jury. Unused as he is generally to witnessing the results of injuries, he is inclined to measure his verdict by the amount of disorder he observes, rather than by the actual amount of disablement the injury has caused. Nor is he aided in this respect by the testimony of medical experts. Conflicting as such testimony usually is, it tends rather to confuse than enlighten him. Perhaps the whole difficulty lies in the fact that the question is too much one of opinion, and not enough of fact. . . ."T

Under workmen's compensation laws the need for a "standard of measurement" is equally acute. The problem in this field has already been faced by the Committee on Economics of the Medical Society of the State of New York which, in its Annual Report for $1933,{ }^{8}$ proposed the following procedure for disability determination, a procedure which suggests an approach to the problem of devising analogous standards for personal injury litigation:

"(a). The determination of temporary, partial, total and permanent disability and of the degree or percentage of disability shall be the duty of one or more physicians qualified under the Law, designated or accepted by the commissioner or referee sitting in the case. Said commissioner or referee shall approve or appeal such determination. He has no authority to arbitrarily alter it.

"(b). In the end result after accident the following shall be used as a general guide for determination of degree of permanent disability; three factors are involved;

r. function, or capacity to perform

2. union, or state of repair of parts

3. contour, or external appearance.

"Inasmuch as function is the most important part in any recovery from accident or disease, it should be assigned the highest percentage of value. Its suggested value is placed at $60 \%$.

"Union, or state of repair, naturally has an effect on the abiliry to perform and also on appearance but can be very imperfect while affording full function and satisfactory appearance. Its suggested valuation is placed at $20 \%$.

"Contour or external appearance, plays an indirect part in ability to perform and in a measure may influence function. Its suggested valuation is placed at $20 \%$. However, if such disability of contour or general appearance is of such character as to reduce future employability its percentage should be increased.

"Illustrative example:

"If in a given case function is only half perfect, allow $30 \%$ disability. If union or repair is half perfect, allow 10\%. If appearance is three-fourths perfect, allow $5 \%$. The end result, then, is 30 plus ro plus 5 , or $45 \%$ disability. Details of evaluation are to be based on "Accidental Injuries" by Kessler, or equally authoritative text.

"Function disturbance may be estimated by this scale regarding the following;

'Id. at 209, II7 Pac. at IrIg. (Italics added.) 'Par. 18, subdiv. 4. 
"Flexion, extension, abduction, adduction, supination, eversion, inversion, apposition, rotation, grip, locomotion, mastication, audition, vision, articulation, sensation, coördination, urination, defecation and other measurable capacity of function."

If a plaintiff were required to specify in his complaint or in a bill of particulars in a personal injury case the extent of deformity, disfigurement and loss of function. for which damages were claimed and to calculate the damages claimed with reference to statutory standards analogous to the above, medical testimony in the trial of the action could be specifically directed to the points thus raised and the basis laid for a much more intelligent verdict, especially if the jury were obliged to render the verdict on special issues composed with reference to these factors. Perhaps more important still, the calculation of damages with reference to such standards would afford the trial and appellate courts a far more effective basis for controlling inadequate and excessive verdicts. The requirement of specification would operate as a deterrent to the type of lawyer who can inflate a broken toe into a claim for $\$ 25,000.00$ damages. An accompanying statutory maximum for damages based on alleged pain and suffering would preclude that element of damage from being resorted to as a means of evading the restrictive effect of the statutory standards.

4. Limit the testimony of the physician attending the injured party to the statement of facts of his observation and care, except in those cases where circumstances preclude an examination of the injured person by independent experts.

Why? Because in the majority of negligence cases the payment of the attending physician for medical care is contingent upon the award the plaintiff receives. Therefore, he is a "contingent fee" witness who has an interest in the outcome of the case; and if he does not make out a good case for the plaintiff, the attorney is more liable than not to tell the family that they "had a good case until the doctor queered it."

5. Limit all expert testimony on medical matters to the opinions of physicians who appear at the trials as the servants of the court, employed and compensated by it, and entirely independent of any interest in the case at issue. Permit parties only to propose to the court the names of experts selected by them from panels of physicians qualified in the various branches of the science of medicine, such panels to be prepared and supervised by the appropriate medical societies.

It scarcely seems necessary to elaborate upon the desirability of an expert witness being the servant of the court and not of either party to the action pending, beyond referring back to Dr. Courtney's comment quoted in the third paragraph in the present paper. It might be of interest to state that Dr. Courtney had adequate occasion to observe the shortcomings of the existent procedure, because he was an expert in a highly controversial field, namely, neuro-psychiatry.

Naturally, there is need for guidance of the court in the selection of qualified expert medical witnesses. An attempt to meet this need has been made in a recent amendment to the Workmen's Compensation Law of New York:9

N. Y. Laws I935, c. 258, \$r, par. 13 (d). 
"The physician to conduct such examination shall be designated by the commissioner from a panel of especially qualified physicians submitted to him by the medical society of the county, or any other board acting for any school of medical practice. Additional names for such panel shall be furnished by the society whenever requested by the commissioner and if such request is not complied with in thirty days the industrial commissioner may add thereto names of his own selection."

8. Experts so chosen should be subject to interrogation only through the court which may utilize appropriate questions submitted to it by counsel.

This is proposed to obviate "the biting sarcasm, the sneers, the raillery and general brow-beating of opposing counsel" to which Dr. Courtney referred in the address already quoted in this paper. If legal readers take exception to this comment, let them be reminded that, at a hearing before a special meeting of the Medical Society of the County of New York in May, r934, a very distinguished New York attorney spoke of having defended a physician "in the face of the leers and jeers and sneers of opposing counsel." The wording is not ours; it is the attorney's. ${ }^{10}$

IV

It is our belief that in a very large percentage of the negligence claim cases, in which we have had personal experience, a simple arbitration hearing could have been arranged promptly, and a satisfactory conclusion of the case established to the economy of the tax-paying public (who support the court), the economy of time of the physicians and other witnesses (who are called upon to appear), and to the ultimate betterment of both parties to the litigation, and to their attorneys. If either the plan which we regard as ideal or the proposals which we offer as compromise substitutes therefor were adopted, the number of cases handled by informal arbitration would, undoubtedly, be vastly increased.

It is our further belief that if a procedure embodying the foregoing principles were put into effect, the legal profession would be subject to less embarrassment from such newspaper editorials as, for example, one in the New York WorldTelegram for September 24, 1935 .

"Have you ever been on a witness stand? Have you ever felt the finger of opposing counsel quivering near your face? Have you ever inhaled the hot breath of a booming and accusative voice bellowing at you to answer 'Yes or no'? Have you ever heard it intimated that you were the one who kidnapped Charley Ross, hit Billy Patterson, caused the panic of ' 93 and brought the yellow fever to Memphis? Well, if you have, you may realize what might occur if a lawyer, always heretofore accustomed to giving it, were suddenly put in a position of taking it, and that he might say things which, in the calm of his study, with all the powers of hindsight brought to bear, didn't look so good. . . . So once again we say we are more than pleased to be magnanimous. To bestow upon Mr. Reed the precious privilege of afterthought, to give him, in fact, a break that we have

\footnotetext{
${ }^{10}$ This subject has been discussed by the junior author in the American lournal of Surgery for October 1934, under the title "Suggestions for Improving Medico-legal Court Procedure." (1934) 24 AM. J. or SURGERY (N. S.) 199.
} 
never seen a lawyer give a witness, to let him express with all due deliberation the very quintessence of what he intended to say."

When, as and if the principles we have outlined are put into effect, we personally can answer for a number of expert medical witnesses of known integrity who will give freely of their services for the purpose of attempting to further justice, who now flatly decline to appear in court for hire by anybody because the present procedure is distasteful to their sense of fair play and decency. 